Review Article

\title{
Natural Products and Biological Activity of the Pharmacologically Active Cauliflower Mushroom Sparassis crispa
}

\author{
Takashi Kimura \\ Research \& Development Center, Unitika Ltd., 23 Uji-Kozakura, Uji, Kyoto 611-0021, Japan \\ Correspondence should be addressed to Takashi Kimura; takashi-kimura@unitika.co.jp
}

Received 4 October 2012; Accepted 25 February 2013

Academic Editor: Fabio Ferreira Perazzo

Copyright (C) 2013 Takashi Kimura. This is an open access article distributed under the Creative Commons Attribution License, which permits unrestricted use, distribution, and reproduction in any medium, provided the original work is properly cited.

Sparassis crispa, also known as cauliflower mushroom, is an edible mushroom with medicinal properties. Its cultivation became popular in Japan about 10 years ago, a phenomenon that has been attributed not only to the quality of its taste, but also to its potential for therapeutic applications. Herein, I present a comprehensive summary of the pharmacological activities and mechanisms of action of its bioactive components, such as beta-glucan, and other physiologically active substances. In particular, the immunomodulatory mechanisms of the beta-glucan components are presented herein in detail.

\section{Introduction}

Medicinal mushrooms have an established history of use in traditional Asian therapies. Over the past 2 to 3 decades, scientific and medical research in Japan, China, and Korea, and more recently in the United States, has increasingly demonstrated the potent and unique properties of compounds extracted from mushrooms for the prevention and treatment of cancer and other chronic diseases. Various important pharmaceutical products with proven medicinal applications have been derived from mushrooms [1].

Sparassis crispa Wulf.:Fr. (Figure 1), also known as cauliflower mushroom, is an edible mushroom with various medicinal properties whose cultivation has recently become popular in Japan. The taxonomy of S. crispa is as follows: kingdom, Fungi; phylum, Basidiomycota; class, Agaricomycetes; order, Polyporales; family, Sparassidaceae; genus, Sparassis; and species, crispa. It is a brown-rot fungus that primarily grows on the stumps of coniferous trees and is widely distributed throughout the North Temperate Zone. S. crispa has been reported to have many biological activities, which are detailed below.

\section{Chemical Constituents and Bioactive Components of $S$. crispa}

Scientific investigation has led to the isolation of many compounds from S. crispa that have been shown to have healthpromoting activities. The fruiting bodies of $S$. crispa contain approximately $90 \%$ water, protein, lipid, carbohydrate, ash, and dietary fiber (Table 1) [3]. Furthermore, the content of vitamin $\mathrm{D}_{2}$, which aids intestinal calcium absorption, was shown to be $0.17 \mathrm{mg}$ per $100 \mathrm{~g}$ of dry weight, a concentration that is higher than that observed in other mushrooms [4]. Also $S$. crispa contained a relatively large amount of glucosyl ceramide (approximately $0.2 \%$ ), which is a glycoside of ceramide. It was demonstrated that the moiety of sphingoid base was characterized by the unique structure [5]. Though S. crispa has a scent of its own, the results of headspace analyses showed that 3-octanone, DL-3-octanol, and 1-octen3 -ol contributed mutually to the particular aroma of this mushroom [6]. It is noteworthy that the beta-glucan content of S. crispa is more than $40 \%$ of the dry weight of the fruiting bodies, as measured by the enzyme method of the Japan Food Research Laboratories (Tokyo) [3] 


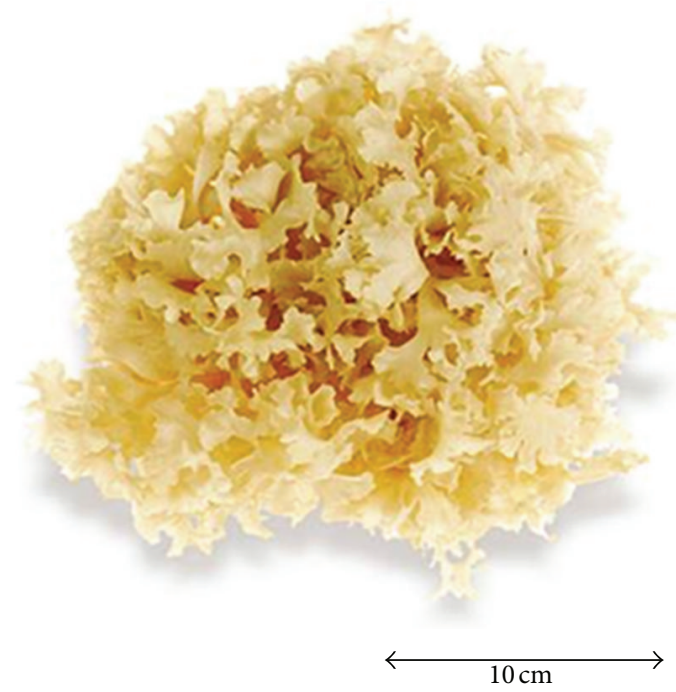

Figure 1: Sparassis crispa Wulf.:Fr. [2].

TABLE 1: Approximate composition of Sparassis crispa (per $100 \mathrm{~g}$ dry sample).

\begin{tabular}{lc}
\hline Components & Amount (g) \\
\hline Protein & 13.4 \\
Fat & 2.0 \\
Ash & 1.8 \\
Carbohydrate & 21.5 \\
Dietary fiber (DF) & 61.2 \\
Beta-glucan from DF & 43.5 \\
\hline
\end{tabular}

\subsection{Polysaccharide (Beta-Glucan)}

2.1.1. Primary Structure. Using chemical, enzymatic, and NMR analyses, it was shown that the primary structure of a purified beta-glucan (designated SCG), obtained from cultured fruiting bodies of S. crispa is a 6-branched 1,3-betaglucan, with one branch in approximately every 3 main chain units (Figure 2) [7-9].

2.1.2. Biological Activities. Tumor size in cancerous (Sarcoma 180) ICR mice was dose-dependently decreased after 5 weeks of oral administration of $S$. crispa (10 or $100 \mathrm{mg} / \mathrm{kg}$ ) in comparison to a control group. Furthermore, the survival rate of these model mice was higher when similarly treated with $S$. crispa [2]. Since SCG content in dry powder of S. crispa was measured to be more than $40 \%$, SCG was likely be responsible for this antitumor effect.

Ohno et al. prepared polysaccharide fractions from the fruiting bodies of cultured S. crispa and showed their antitumor activity against the solid form of Sarcoma 180 in ICR mice with strong vascular dilation and hemorrhage reactions [7]. Furthermore, intraperitoneal and oral SCG over a wide range of concentrations enhanced hematopoietic responses in mice with leukopenia induced by cyclophosphamide (CY, a DNA-alkylating agent) $[10,11]$. This effect was augmented in combination with isoflavone aglycone [12]. SCG was also shown to stimulate leukocytes to produce cytokines such as IL-8 in whole-cell cultures of human peripheral blood [13] and in mouse splenocytes [14].

Yamamoto et. al reported antiangiogenic and antimetastatic effects of SCG on neoplasm by using different animal models [8]. Oral administration of SCG suppressed B16-F10 cell-induced angiogenesis in a dorsal air sac assay using ICR mice and suppressed vascular endothelial growth factor induced neovascularization in a Matrigel plug assay using C57BL/6J mice. Furthermore, it suppressed the growth and number of metastatic tumor foci in the lung, along with primary tumor growth in a C57BL/6J mice model of spontaneous metastasis. From these findings, it is apparent that the oral administration of SCG exerts a suppressive effect on tumor growth and metastasis in the lung through the inhibition of tumor-induced angiogenesis.

Taken together, these results demonstrate that SCG exhibits various biological activities, including antitumor effects, enhancement of the hematopoietic response, and induction of cytokine production in vivo and in vitro.

2.1.3. Mechanisms. Harada et al. reported strain-specific differences of the reactivity of mice to SCG, with DBA/1 and $\mathrm{DBA} / 2$ mice being highly sensitive to SCG. In splenocytes derived from various inbred strains of mice, interferon- $\gamma$ $(\mathrm{IFN}-\gamma)$ production was not induced by SCG. However, splenocytes from naïve $\mathrm{DBA} / 1$ and $\mathrm{DBA} / 2$ mice strongly react with SCG to produce IFN- $\gamma$ [14]. Furthermore, in addition to IFN- $\gamma$, cytokines induced by SCG were screened for and found to include tumor necrosis factor- $\alpha$ (TNF- $\alpha$ ), granulocyte-macrophage colony-stimulating factor (GM-CSF), and interleukin-12 (IL-12p70) [15]. Since the sera of naïve DBA/1 and DBA/2 mice contain significantly higher titers of antibody against SCG than other strains of mice [16], it seems likely that these mice strains are sensitive to SCG. Thus, DBA/1 and DBA/2 mice would be useful models for future studies of SCG.

Harada et al. further demonstrated that GM-CSF was one of the key factors in reactivity to SCG in DBA/2 mice $[15,17]$. Neutralizing GM-CSF using an anti-GM-CSF monoclonal antibody significantly inhibited IFN- $\gamma$, TNF- $\alpha$, and IL- 12 p70 elicited by SCG. The splenocytes in various strains of mice showed similar patterns of cytokine production in response to SCG cotreatment in the presence of recombinant murine GM-CSF. The high sensitivity to SGG shown by DBA/1 and DBA/2 mice may be attributable to differences of their regulation of GM-CSF compared with that in other mice.

Harada and Ohno also proposed an interesting model for the mechanism of cytokine induction by SCG in DBA/2 mice [18]. Broadly speaking, SCG directly induces adherent cells to produce TNF- $\alpha$ and IL-12p70, whereas cell-cell contact mediated by the association of $\mathrm{CD}^{+}{ }^{+} \mathrm{T}$ cells expressing LFA-1 and antigen-presenting cells such as dendritic cells expressing ICAM-1 is required for the induction of IFN- $\gamma$ and GM-CSF by SCG.

Neutrophils, macrophages, and dendritic cells express several receptors capable of recognizing beta-glucan in its 


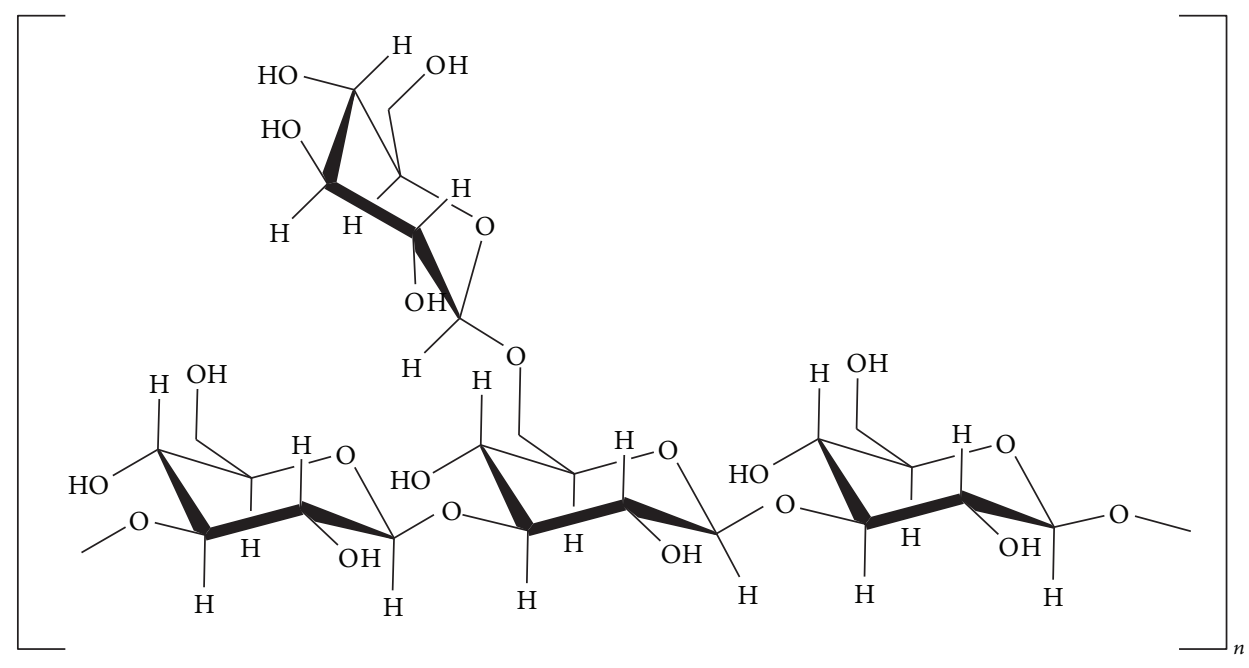

FIGURE 2: Chemical structure of SCG [9].

various forms. Dectin-1, complement receptor 3, lactosylceramide, and scavenger and Toll-like receptors are all candidates that have been reported thus far [19-23]. Among these, dectin-1, which is a C-type lectin, is an archetypical non-Tolllike pattern recognition receptor expressed predominantly by myeloid cells. Dectin-1 can induce its own intracellular signaling and can mediate a variety of cellular responses, such as cytokine production [24].

The magnitude of cytokine induction from bonemarrow-derived dendritic cells (BMDCs) by SCG and the expression level of dectin-1 on BMDCs in DBA/2 mice are both higher than that of other strains of mice. Furthermore, blocking dectin-1 significantly inhibits the induction of TNF- $\alpha$ production by SCG. These results suggest that the BMDCs from DBA/2 mice are highly sensitive to SCGinduced cytokine production in vitro, and that this sensitivity is related to the expression level of dectin-1 [25].

The molecular mechanism of the enhanced hematopoietic response has been investigated in CY-treated mice (both ICR and C57BL/6 strains) [26]. According to this report, the levels of IFN- $\gamma$, TNF- $\alpha$, GM-CSF, IL- 6 , and IL-12p70 were all shown to be significantly increased in SCG-treated splenocytes of CY-treated mice. GM-CSF production in the splenocytes of CY-treated mice was reportedly higher than that in normal mice regardless of SCG stimulation. Neutralizing GM-CSF significantly inhibited the induction of IFN- $\gamma$, TNF- $\alpha$, and IL-12p70 by SCG. The level of cytokine induction by SCG was modulated by the amount of endogenous GM-CSF produced in response to CY treatment in a dose-dependent manner. The expression of beta-glucan receptors, such as CR3 and dectin-1, was upregulated by CY treatment. Blocking dectin-1 significantly inhibited the induction of TNF- $\alpha$ and IL-12p70 production by SCG. Taken together, these results suggest that the key factors in cytokine induction in CY-treated mice are the enhanced levels of both endogenous GM-CSF production and dectin-1 expression. It is very interesting that agents that modulate GM-CSF production and dectin-1 expression, such as CY, can control reactivity to SCG and the expression of various cytokines.

Shibata et al. found that both GM-CSF and TNF- $\alpha$ synthesis in DBA/2 mouse splenocytes stimulated with SCG, but not with lipopolysaccharide, were significantly enhanced in the presence of cytochalasin D (CytD), an inhibitor of actin polymerization [27]. On the other hand, Kim et al. pointed out the importance of the role of Toll-like receptor 4 (TLR4) [28]. They examined the effect of SCG on adherent monocytes, such as macrophages and dendritic cells (DCs), and nonadherent lymphocytes, such as T and B cells, and demonstrated that SCG mainly activated DCs and macrophages, but not T and B cells. The role of TLR4 as a membrane receptor of SCG was shown by the impairment of maturation of DCs generated from bone marrow cells of tlr4 $4^{-} /^{-}$knockout mice and TLR4-mutated C3H/HeJ mice, and by using an anti-MD-2/TLR4 neutralizing antibody. SCG increased the phosphorylation of ERK, p38, and JNK and enhanced nuclear translocation of NF- $\kappa \mathrm{B}$ p50/p65 in DCs. These results indicate that SCG activates DCs via MAPK and $\mathrm{NF}-\kappa \mathrm{B}$ signaling pathways, which are signaling molecules downstream of TLR4.

2.2. Low-Molecular-Weight Compounds. S. crispa possesses a wide range of bioactive metabolites which are products of secondary metabolism (Figure 3 ).

2.2.1. Antimicrobial Compounds. It has been reported that $S$. crispa produces antibiotic substances. For example, suppression of Bacillus subtilis growth on agar media is known to be due to sparassol (methyl-2-hydroxy-4-methoxy-6methylbenzoate) (1) [29]. Woodward et al. reported that $S$. crispa produced 3 antifungal compounds when submerged in culture in a $2 \%$ malt broth. The compounds included 
sparassol, and two other antifungal compounds, methyl2,4-dihydroxy-6-methylbenzoate (2) and methyl-dihydroxymethoxy-methylbenzoate (the positions of substituents were unclear), both of which showed higher antifungal activity than sparassol against Cladosporium cucumerinum [30].

A novel compound (4) and a previously known one (3) were isolated from S. crispa [31]. Both compounds were shown to inhibit both melanin synthesis and methicillinresistant Staphylococcus aureus (MRSA) growth. The minimum inhibitory concentration (MIC) values of compounds 3 and 4 in the anti-MRSA assay were 0.5 and $1.0 \mathrm{mM}$, respectively. $\mathrm{IC}_{50}$ values of compounds (3) and (4) in the melanin production inhibition assay were $33 \mu \mathrm{M}$ and $12 \mu \mathrm{M}$, respectively. Since the $\mathrm{IC}_{50}$ value of an existing whitening agent, arbutin, is reported to be $1.32 \mathrm{mM}$, these compounds have potential as constituents of cosmetic products.

In the course of screening for compounds that inhibit MRSA growth, Kodani et al. discovered 2 known chalcones, xanthoangelol (5) and 4-hydroxyderricin (6), in the extract of $S$. crispa, which have been previously isolated from the plant Angelica keiskei. These compounds showed anti-MRSA activity, and their MICs were 2 and $0.25 \mathrm{mM}$, respectively. This was the first report of the isolation of chalcones from a representative of the Fungi kingdom [32].

2.2.2. Other Bioactive Compounds. A new sesquiterpenoid was also isolated from $S$. crispa [33]. Its structure was determined to be $\left(3 \mathrm{R}^{*}, 3 \mathrm{aS}^{*}, 4 \mathrm{~S}^{*}, 8 \mathrm{aR}^{*}\right)-3$ - $\left(1^{\prime}\right.$-hydroxy$1^{\prime}$-methylethyl)-5,8a-dimethyldecahydroazulen-4-ol (7) by a combination of NMR and ESI-MS analyses. This was the first isolation of an isodaucane-type sesquiterpenoid from a fungus, including mushrooms.

Yoshikawa et al. isolated three novel phthalides, designated hanabiratakelide A (8), B (9), and C (10) in addition to three known phthalides, from the S. crispa fruiting body [34]. The 6 isolated compounds were tested for their antioxidant activity. The in vitro superoxide dismutase-like activity of the three hanabiratakelides was stronger than that of vitamin C. These compounds also inhibited lipopolysaccharidestimulated nitric oxide and prostaglandin E2 production by a murine macrophage cell line, RAW264. In addition, the growth of the colon cancer cell lines Caco-2 and colon-26 was significantly inhibited by treatment with all 3 of the hanabiratakelides.

\section{Pharmacological Aspects of S. crispa}

3.1. Antiviral Activity. Reverse transcriptase (RT) is one of the key enzymes in human immunodeficiency virus (HIV) replication. HIV replication is interfered with when the enzyme is inhibited. Thus, RT inhibitors can be used to treat AIDS. Hot water extracts from the fruiting bodies of 16 species of mushroom, including $S$. crispa, were screened for HIV-1 RT inhibitory activity. The extract of S. crispa elicited $70.3 \%$ inhibition when tested at a concentration of $1 \mathrm{mg} / \mathrm{mL}$. However, the active component remains unclear [35].

3.2. Antihypertensive Effects. One of the main causes of stroke is hypertension. Therefore, it is important to avoid high blood pressure as a preventative measure. Yoshitomi et al. investigated not only the preventive effects of S. crispa against stroke and hypertension in stroke-prone spontaneously hypertensive rats (SHRSP), but also the mechanism involved by studying the cerebral cortex [36]. SHRSP rats given feed containing $1.5 \%$ S. crispa had a delayed incidence of stroke and death, significantly decreased blood pressure, and increased blood flow. Moreover, the urinary nitrate/nitrite excretion and the nitrate/nitrite concentration in cerebral tissue were higher than those of control SHRSP rats. In the cerebral cortex, phosphor-eNOS (Ser1177) and phosphorAkt (Ser473) in S. crispa-treated SHRSP rats were increased compared with those of control SHRSP rats. In conclusion, S. crispa can ameliorate cerebrovascular endothelial dysfunction by promoting recovery of Akt-dependent eNOS phosphorylation and increasing nitric oxide (NO) production in the cerebral cortex.

In addition, Lee et al. indicated that SCG was able to stimulate NO production as well as enhance the expression of inducible NO synthase (iNOS) from macrophagelike RAW264.7 cells [37]. Since NO production is strongly suppressed by mitogen-activated protein kinase (MAPK) inhibitors, it is likely that SGG-induced NO release is mediated by MAPK.

3.3. Antidiabetic Activity. It has been shown that dietary $S$. crispa improves the symptoms of both type 1 and type 2 diabetes. The consumption of a diet containing more than $0.5 \%$ S. crispa results in significant improvement in diabetes symptoms (body weight loss and increased blood glucose) in ICR mice with STZ-induced diabetes [38]. Furthermore, Yamamoto and Kimura examined the effect of dietary $S$. crispa on KK-Ay mice, an animal model of type 2 diabetes mellitus [39]. The group that was fed 5.0\% S. crispa diet showed not only a significant decrease of blood glucose and insulin levels, but also a pronounced increase in plasma levels of adiponectin in comparison with a control group. Although the S. crispa diet had no effect on body and adipose tissue weights in KK-Ay mice, the size of the mesenteric adipose cells of mice in the $S$. crispa group tended to be smaller than the control group. Thus, the S. crispa diet may decrease the adipose cell size in order to increase plasma adiponectin levels. Considering the physiological significance of adiponectin, these findings imply that dietary $S$. crispa has the potential to ameliorate type 2 diabetes.

GPR40 is one of the G protein-coupled receptors, which has 7 transmembrane spanning helical bundles. GPR40 distributes in pancreas and central nervous system. It can be bound by medium- and long-chain fatty acid and activate the intracellular signal pathways, which in turn regulates the function of cells. In pancreatic beta-cell, intracellular calcium concentration elevates when GPR40 is binding to fatty acid, thereby promoting the release of insulin [40]. Yoshikawa et al. demonstrated that a couple of unsaturated fatty acids in $S$. crispa were the agonist of GPR40, which might be used for preventing and treating the diabetes [41].

The normal healing process in healthy individuals takes place at an optimal rate, but it is usually delayed, or even 
<smiles>COC(=O)c1c(C)cc(OC)cc1O</smiles>

(1)<smiles>COC(=O)c1c(C)cc(O)cc1O</smiles>

(2)<smiles>CC(C)=CCOc1ccc(C2C(=O)N(O)C(=O)[C@H]2CC(C)C)cc1</smiles>

(3)<smiles>CC(C)=CCOc1ccc(C2=C(CC(C)C)C(=O)N(O)C2=O)cc1</smiles>

(4)<smiles>CC(C)=CCC/C(C)=C/Cc1c(O)ccc(C(=O)/C=C/c2ccc(O)cc2)c1O</smiles>

(5)<smiles>COc1ccc(C(=O)/C=C/c2ccc(O)cc2)c(O)c1CC=C(C)C</smiles>

(6)<smiles>COc1cc2c(c(O)c1O)COC2=O</smiles>

(8)<smiles>COc1c(O)cc2c(c1O)C(=O)OC2</smiles>

(9)

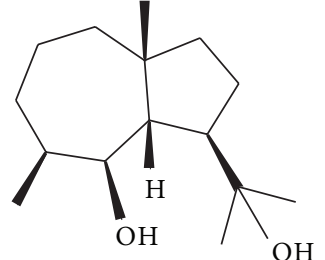

(7)<smiles>COc1c(O)c(O)c(O)c2c1C(=O)OC2</smiles>

(10)

Figure 3: Chemical structure of the low-molecular-weight compounds found in S. crispa [29-34].

completely impaired in patients with diabetes. Thus, the impaired wound healing that occurs in diabetes mellitus is a major clinical problem. It is also generally accepted that wound repair is an immune-mediated physiologic mechanism. Oral administration of $1,000 \mathrm{mg} / \mathrm{kg}$ body weight per day of S. crispa for 4 weeks was shown to significantly accelerate wound healing in rats with streptozotocin- (STZ-) induced diabetes, which is an insulin-dependent model of diabetes mellitus (type 1) [42]. Furthermore, in S. crispatreated wounds there were significant increase in macrophage and fibroblast migration, collagen regeneration, and epithelialization compared with a control group. Therefore, the use 
of S. crispa may be extended to the clinical setting, and it may effectively promote wound healing in patients with diabetes.

Yamamoto and Kimura investigated whether oral and topical administration of $S$. crispa could restore effective wound healing in ICR mice with STZ-induced diabetes [38]. Mice consuming a diet containing more than $0.5 \%$ S. crispa showed significantly improved wound healing. Notably, the rate of wound healing in mice fed a diet containing $2.5 \%$ S. crispa was almost the same as that in mice treated with topical trafermin (basic fibroblast growth factor formulation). Moreover, topically administered SCG significantly promoted wound healing in mice with diabetes, resulting in a wound contraction ratio of $37 \%$ after treatment for 9 days, a result that was superior to that of trafermin.

3.4. Antitumor and Anticarcinogenic Activity (except for SCG). Yamamoto et al. investigated the antitumor effects of a low-molecular-weight (below approximately $8 \mathrm{kDa}$ ) fraction (FHL) containing no beta-glucan isolated from a hot water extract of S. crispa [43]. The oral administration of FHL $(30 \mathrm{mg} / \mathrm{kg}$ ) to tumor- (sarcoma 180) bearing ICR mice was observed to suppress tumor growth. Furthermore, the IFN- $\gamma$ level in the culture supernatant of splenic lymphocytes from FHL-fed tumor-bearing mice was significantly increased compared to a control group. Tumor-induced angiogenesis in the dorsal air sac (DAS) system was also suppressed by FHL administration. These results suggest that the oral administration of FHL induces antitumor activity through the enhancement of the Th1-response in tumor-bearing mice. Additionally, the antiangiogenic activity of FHL may contribute to its antitumor activity.

Yoshikawa et al. investigated the possible preventive effects of $S$. crispa on azoxymethane-induced colon aberrant crypt foci (ACF) in F344/N rats. S. crispa feeding dosedependently suppressed the malignant changes of ACF by $54 \%$ ( $0.3 \%$ group), $64 \%$ (1.0\% group), and $75 \%$ (3.0\% group). They concluded that the anticancer-related activity may originate from the aforementioned hanabiratakelides [34].

3.5. Antiallergic Activity. Allergic inflammatory diseases, such as food allergy, asthma, hay fever, and atopic dermatitis, are increasing worldwide. Some recent reports have demonstrated antiallergic activities of S. crispa. Atopic dermatitis $(\mathrm{AD})$ is a common inflammatory skin disease for which few effective treatments are available. Oral administration of $250 \mathrm{mg} / \mathrm{kg}$ body weight per day of $S$. crispa decreased both blood immunoglobulin E (IgE) level and scratching index in $\mathrm{Nc}$ /Nga mice with dermatitis induced by a continuous application of 2,4,6-trinitrochlorobenzene [2]. In addition, the antirhinitis properties of $S$. crispa were also investigated in mice [44]. To determine the immunomodulatory activity of oral S. crispa, splenocytes obtained from ovalbuminsensitized BALB/c mice fed $0.25 \%$ S. crispa were restimulated in vitro with the same antigen. The oral $S$. crispa induced IFN- $\gamma$ secretion, but inhibited IL- 4 and IL- 5 secretion, and suppressed ovalbumin-specific IgE secretion by the splenocytes. The effects of $S$. crispa were further investigated by using an allergic rhinitis model in BALB/c mice. Nasal symptoms, sneezing, and nasal rubbing induced by ovalbumin challenges were inhibited by oral administration of S. crispa (36 or $120 \mathrm{mg} / \mathrm{kg}$ ) in a dose-dependent manner. Furthermore, ovalbumin-specific serum IgE levels were diminished by $S$. crispa treatment in this model. These results demonstrate that $S$. crispa may be effective in suppressing symptoms of allergic rhinitis through suppression of the Th2-type immune response.

Kim et al. reported the effect of a water extract of $S$. crispa (WESC) on mast-cell-mediated allergic inflammation and the possible mechanisms of action using in vivo and in vitro models [45]. WESC inhibited compound 48/80induced systemic anaphylaxis and serum histamine release in mice. WESC decreased IgE-mediated passive cutaneous anaphylaxis. Additionally, WESC reduced histamine release and intracellular calcium in human mast cells activated by both phorbol 12-myristate 13-acetate (PMA) and calcium ionophore A23187. Since intracellular calcium plays an important role in the release of histamine and the expression of cytokines, the decreased intracellular calcium levels may be involved in the inhibitory effect of WESC on histamine release. WESC decreased PMA and A23187stimulated expression of proinflammatory cytokines, such as TNF- $\alpha$, interleukin- (IL-6), and IL- $1 \beta$. The inhibitory effect of WESC on proinflammatory cytokines was shown to be dependent on nuclear factor- $\kappa \mathrm{B}$, extracellular signalregulated kinase, and p38 mitogen-activated protein kinase. Since the beta-glucan content in WESC was measured to be $39.3 \%$, beta-glucan may be responsible for its antiallergic effects.

\section{Human Clinical Evaluation}

In a study where healthy men were given $S$. crispa powder orally at $300 \mathrm{mg}$ per day for 8 weeks, NK cell cytotoxicity was significantly enhanced without increasing the number of NK cells when compared to preadministration [2]. In addition, Kimura investigated whether dietary S. crispa influenced human skin condition [46]. Oral administration of S. crispa powder ( $320 \mathrm{mg} /$ day) for 28 consecutive days dramatically reduced transepidermal water loss, an indicator of the skin barrier condition, while that of a placebo group was unchanged during the testing period. These observations imply that oral administration of $S$. crispa has a positive effect on the skin barrier.

A clinical trial of $S$. crispa used an orally delivered powder (300 mg/day) in patients with several different types of cancer (lung, stomach, colon, breast, ovarian, uterine, prostate, pancreas, and liver cancers) after the patients had received a single course of lymphocyte transfer immunotherapy [47]. Patient assessment of 14 cases after a several month followup period (mean: 15 months) revealed that the performance status in 9 cases showed improvement in quality of life, and so forth.

\section{Conclusions and Future Prospects}

S. crispa has been described in the literature as a mushroom with great potential for therapeutic applications. The 
medicinal value of this mushroom is mainly attributable to its abundant 6-branched 1,3-beta-glucan (SCG). By chemical analysis, we found that the primary structure of a purified beta-glucan obtained from liquid cultured mycelium of $S$. crispa was a 6-branched 1,3-beta-glucan, having one branch approximately every 6 residues, with a degree of branching that is relatively less than that of SCG. The effect on tumor(sarcoma 180) bearing ICR mice was much weaker than that of SCG given by oral administration (data not shown). Furthermore, using 1D- and 2D-NMR spectroscopy, Tada et al. elucidated the fine primary structure of SCG and compared it with sonifilan (SPG) from Schizophyllum commune, which is a 6-branched 1,3-beta-glucan and has been used clinically for cancer therapy in Japan, examining differences in the biological effects between these beta-glucans [9]. Though both major structural units are the same beta-(1-3)-glucan backbone with single beta-(1-6)-glucosyl side branching units every 3 residues, the production of IL- 6 and TNF-alpha from BMDCs was significantly increased by SCG, whereas these effects were not observed with SPG treatment. These findings may indicate that the biological activities of betaglucan are attributable not only to its primary structure but also to its conformation.

Though it has been suggested that dietary S. crispa is useful for cancer immunotherapy in combination with lymphocyte transplantation [47], the study described in this previous report did not include a randomized control group. Further clinical trials are needed to confirm the pharmacological activity of dietary S. crispa. There is still little scientific evidence to explain the differences in responsiveness to betaglucan in humans. The studies of differences in reactivity to SCG in different animal strains $[14,15,17]$ are important from this viewpoint. Furthermore, it is interesting that agents such as CY can control reactivity to SCG, as well as the expression of various cytokines [26]. Further research on reactivity to SCG could provide clues for developing more effective cancer immunotherapies using SCG.

As mentioned above, dectin-1 and TLR4 have been proposed as SCG receptors. It is noteworthy that either treatment with a blocking antibody against dectin-1 $[25,26]$ or genetic deletion of TLR4 [28] completely prevents SCG-induced DC maturation. These observations might indicate that one signaling pathway did not compensate for the other in SCGtreated DCs, suggesting that both receptors are required for SCG action. However, further analysis of the role of these receptor candidates, which contain complement receptor 3 , lactosylceramide, and scavenger-like receptors, in response to SCG would be needed in order to clarify the details of its mechanism of action in DCs [48].

The question has been raised as to how orally administered beta-glucan exerts its effects. The evidence presented in this review clearly indicates that dietary SCG has immunomodulatory actions. Therefore, it must be assumed that orally ingested SCG interacts with either intestinal epithelial cells and/or intestinal DCs, ultimately resulting in the priming or activation of other immune cells.

The antitumor mechanisms of SCG, except for its immunomodulatory actions, have not been well studied. Hence, we tried to elucidate the possible mechanisms of its antiangiogenic effects. As a result, it was demonstrated that SCG has both antiangiogenic functions and antimetastatic effects on neoplasm using different animal models [8]. The antitumor effects of SCG may be partially attributable to its antiangiogenic actions. Numerous reports concerning the antitumor activity of edible mushrooms have taken particular notice of beta-glucan. However, few studies have focused on antitumor components other than beta-glucan. It is worth mentioning that $S$. crispa has been shown to produce some low-molecular-weight constituents with antitumor activity, such as hanabiratakelide [34] and FHL [43].

Recently, Park et al. reported a novel process for nanoparticle extraction of beta-D-glucan from S. crispa using insoluble tungsten carbide [49]. This nanoknife method results in high yields of SCG (70.2\%) with an average particle size of 150 and $390 \mathrm{~nm}$. The extracted SCG showed a remarkably high water solubility of $90 \%$ at room temperature. This nanoknife method could be a potent technology to produce SCG for food, cosmetics, and pharmaceutical industries.

The extract of $S$. crispa might be applied to produce health products such as food, beverage, and antineoplastic drug. Actually, S. crispa extractions, resveratrol, and collagen peptide were claimed as antiaging agents and food supplements [50]. Formulation examples of granules and health drinks were disclosed.

Many people in Japan consume S. crispa, and to date, no reports of adverse events due to $S$. crispa consumption have been reported. Therefore, dietary treatment with $S$. crispa may prove to be a safe therapy for cancer and other chronic diseases.

\section{References}

[1] S. P. Wasser and A. L. Weiss, "Medicinal properties of substances occurring in higher basidomycetes mushrooms: current perspectives," International Journal of Medicinal Mushrooms, vol. 1, pp. 31-62, 1999.

[2] A. Hasegawa, M. Yamada, M. Dombo, R. Fukushima, N. Matsuura, and A. Sugitachi, "Sparassis crispa as biological response modifier," Gan To Kagaku Ryoho, vol. 31, no. 11, pp. 1761-1763, 2004.

[3] T. Kimura and M. Dombo, "Sparassis crispa," in Biological Activities and Functions of Mushrooms, H. Kawagishi, Ed., pp. 167-178, CMC Press, Tokyo, Japan, 2005.

[4] H. J. Shin, D. S. Oh, H. D. Lee, H. B. Kang, C. W. Lee, and W. S. Cha, "Analysis of mineral, amino acid and vitamin contents of fruiting body of Sparassis crispa," in Journal of Life Sciences, vol. 17, pp. 1290-1293, 2007.

[5] M. Dombo, K. Matumura, K. Yuki, and T. Kimura, "Ceramides from Sparassis crispa," Japanese Kokai Tokkyo Koho, P2005206576A (August, 2005).

[6] Q. Wang, J. Li, Y. Wang, X. Zhang, and K. Li, "Comparison of aromatic components from Sparassis crispa extracted by Static Headspace and Headspace-SPME," Shipin Gongye Keji, vol. 32, no. 11, pp. 174-176, 2011.

[7] N. Ohno, N. N. Miura, M. Nakajima, and T. Yadomae, "Antitumor 1,3- $\beta$-glucan from cultured fruit body of Sparassis crispa," Biological and Pharmaceutical Bulletin, vol. 23, no. 7, pp. 866872, 2000. 
[8] K. Yamamoto, T. Kimura, A. Sugitachi, and N. Matsuura, "Anti-angiogenic and anti-metastatic effects of $\beta-1,3-D$-glucan purified from hanabiratake, Sparassis crispa," Biological and Pharmaceutical Bulletin, vol. 32, no. 2, pp. 259-263, 2009.

[9] R. Tada, T. Harada, N. Nagi-Miura et al., "NMR characterization of the structure of a $\beta$ - $(1 \rightarrow 3)$-D-glucan isolate from cultured fruit bodies of Sparassis crispa," Carbohydrate Research, vol.342, no. 17, pp. 2611-2618, 2007.

[10] T. Harada, N. Miura, Y. Adachi, M. Nakajima, T. Yadomae, and N. Ohno, "Effect of SCG, 1,3- $\beta$-D-glucan from Sparassis crispa on the hematopoietic response in cyclophosphamide induced leukopenic mice," Biological and Pharmaceutical Bulletin, vol. 25, no. 7, pp. 931-939, 2002.

[11] N. Ohno, T. Harada, S. Masuzawa et al., "Antitumor activity and hematopoietic response of beta-glucan extracted from an edible and medicinal mushroom Sparassis crispa Wulf.:Fr. (Aphyllophoromycetideae)," International Journal of Medicinal Mushrooms, vol. 4, pp. 13-26, 2002.

[12] T. Harada, S. Masuda, M. Arii et al., "Soy isoflavone aglycone modulates A hematopoietic response in combination with soluble $\beta$-glucan: SCG," Biological and Pharmaceutical Bulletin, vol. 28, no. 12, pp. 2342-2345, 2005.

[13] S. Nameda, T. Harada, N. N. Miura et al., "Enhanced cytokine synthesis of leukocytes by a $\beta$-glucan preparation, SCG, extracted from a medicinal mushroom, Sparassis crispa," Immunopharmacology and Immunotoxicology, vol. 25, no. 3, pp. 321-335, 2003.

[14] T. Harada, N. N. Miura, Y. Adachi, M. Nakajima, T. Yadomae, and N. Ohno, "IFN- $\gamma$ induction by SCG, 1,3- $\beta$-D-glucan from Sparassis crispa, in DBA/2 mice in vitro," Journal of Interferon and Cytokine Research, vol. 22, no. 12, pp. 1227-1239, 2002.

[15] T. Harada, N. N. Miura, Y. Adachi, M. Nakajima, T. Yadomae, and N. Ohno, "Granulocyte-Macrophage Colony-Stimulating Factor (GM-CSF) regulates cytokine induction by $1,3-\beta-\mathrm{D}$ glucan SCG in DBA/2 mice in vitro," Journal of Interferon and Cytokine Research, vol. 24, no. 8, pp. 478-489, 2004.

[16] T. Harada, N. N. Miura, Y. Adachi, M. Nakajima, T. Yadomae, and N. Ohno, "Antibody to soluble 1,3/1,6- $\beta$-D-glucan, SCG in sera of naive DBA/2 mice," Biological and Pharmaceutical Bulletin, vol. 26, no. 8, pp. 1225-1228, 2003.

[17] R. Tada, M. Yoshikawa, T. Kuge et al., "Granulocyte macrophage colony-stimulating factor is required for cytokine induction by a highly 6-branched 1,3- $\beta$-D-glucan from Aureobasidium pullulans in mouse-derived splenocytes," Immunopharmacology and Immunotoxicology, vol. 33, no. 2, pp. 302-308, 2011.

[18] T. Harada and N. Ohno, "Contribution of dectin-1 and granulocyte macrophage-colony stimulating factor (GM-CSF) to immunomodulating actions of $\beta$-glucan," International Immunopharmacology, vol. 8, no. 4, pp. 556-566, 2008.

[19] M. Sato, H. Sano, D. Iwaki et al., "Direct binding of toll-like receptor 2 to zymosan, and zymosan-induced NF- $\kappa$ B activation and TNF- $\alpha$ secretion are down-regulated by lung collectin surfactant protein A," The Journal of Immunology, vol. 171, no. 1, pp. 417-425, 2003.

[20] B. P. Thornton, V. Vĕtvicka, M. Pitman, R. C. Goldman, and G. D. Ross, "Analysis of the sugar specificity and molecular location of the beta-glucan binding lectin site of complement receptor type 3 (CD11b/CD18)," The Journal of Immunology, vol. 156, pp. 1235-1246, 1996.

[21] P. J. Rice, J. L. Kelley, G. Kogan et al., "Human monocyte scavenger receptors are pattern recognition receptors for $(1 \rightarrow$
3)- $\beta$-D-glucans," Journal of Leukocyte Biology, vol. 72, no. 1, pp. 140-146, 2002.

[22] J. W. Zimmerman, J. Lindermuth, P. A. Fish, G. P. Palace, T. T. Stevenson, and D. E. DeMong, "A novel carbohydrateglycosphingolipid interaction between a $\beta$-(1-3)-glucan immunomodulator, PGG-glucan, and lactosylceramide of human leukocytes," The Journal of Biological Chemistry, vol. 273, no. 34, pp. 22014-22020, 1998.

[23] G. D. Brown, P. R. Taylor, D. M. Reid et al., "Dectin-1 is a major $\beta$-glucan receptor on macrophages," Journal of Experimental Medicine, vol. 196, no. 3, pp. 407-412, 2002.

[24] D. M. Reid, N. A. Gow, and G. D. Brown, "Pattern recognition: recent insights from Dectin-1," Current Opinion in Immunology, vol. 21, no. 1, pp. 30-37, 2009.

[25] T. Harada, N. N. Miura, Y. Adachi, M. Nakajima, T. Yadomae, and N. Ohno, "Highly expressed dectin-1 on bone marrowderived dendritic cells regulates the sensitivity to $\beta$-glucan in DBA/2 mice," Journal of Interferon and Cytokine Research, vol. 28, no. 8, pp. 477-486, 2007.

[26] T. Harada, H. Kawaminami, N. N. Miura et al., "Mechanism of enhanced hematopoietic response by soluble $\beta$-glucan SCG in cyclophosphamide-treated mice," Microbiology and Immunology, vol. 50, no. 9, pp. 687-700, 2006.

[27] A. Shibata, T. H. Hida, K. Ishibashi, N. N. Miura, Y. Adachi, and N. Ohno, "Disruption of actin cytoskeleton enhanced cytokine synthesis of splenocytes stimulated with beta-glucan from the cauliflower medicinal mushroom, Sparassis crispa Wulf.:Fr. (higher Basidiomycetes) in vitro," International Journal of Medicinal Mushrooms, vol. 14, no. 3, pp. 257-269, 2012.

[28] H. S. Kim, J. Y. Kim, H. S. Ryu et al., "Induction of dendritic cell maturation by $\beta$-glucan isolated from Sparassis crispa," International Immunopharmacology, vol. 10, no. 10, pp. 12841294, 2010.

[29] R. Siepmann, "Wachstumshemmung von Stammfaulepilzen und von Gremmeniella abietina durch Bacillus subtilis," European Journal of Forest Pathology, vol. 17, pp. 59-64, 1987.

[30] S. Woodward, H. Y. Sultan, D. K. Barrett, and R. B. Pearce, "Two new antifungal metabolites produced by Sparassis crispa in culture and in decayed trees," Journal of General Microbiology, vol. 139, no. 1, pp. 153-159, 1993.

[31] H. Kawagishi, K. Hayashi, S. Tokuyama, N. Hashimoto, T. Kimura, and M. Dombo, "Novel bioactive compound from the Sparassis crispa mushroom," Bioscience, Biotechnology and Biochemistry, vol. 71, no. 7, pp. 1804-1806, 2007.

[32] S. Kodani, K. Hayashi, S. Tokuyama et al., "Occurrence and identification of chalcones from the culinary-medicinal cauliflower mushroom Sparassis crispa (Wulf.) Fr. (Aphyllophoromycetideae)," International Journal of Medicinal Mushrooms, vol. 10, no. 4, pp. 331-336, 2008.

[33] S. Kodani, K. Hayashi, M. Hashimoto, T. Kimura, M. Dombo, and H. Kawagishi, "New sesquiterpenoid from the mushroom Sparassis crispa," Bioscience, Biotechnology and Biochemistry, vol. 73, no. 1, pp. 228-229, 2009.

[34] K. Yoshikawa, N. Kokudo, T. Hashimoto, K. Yamamoto, T. Inose, and T. Kimura, "Novel phthalide compounds from Sparassis crispa (Hanabiratake), Hanabiratakelide A-C, exhibiting anti-cancer related activity," Biological and Pharmaceutical Bulletin, vol. 33, no. 8, pp. 1355-1359, 2010.

[35] J. Wang, H. X. Wang, and T. B. Ng, "A peptide with HIV-1 reverse transcriptase inhibitory activity from the medicinal mushroom Russula paludosa," Peptides, vol. 28, no. 3, pp. 560-565, 2007. 
[36] H. Yoshitomi, E. Iwaoka, M. Kubo, M. Shibata, and M. Gao, "Beneficial effect of Sparassis crispa on stroke through activation of Akt/eNOS pathway in brain of SHRSP," Journal of Natural Medicines, vol. 65, no. 1, pp. 135-141, 2011.

[37] S. Y. Lee, Y. G. Lee, S. E. Byeon et al., "Mitogen activated protein kinases are prime signalling enzymes in nitric oxide production induced by soluble $\beta$-glucan from Sparassis crispa," Archives of Pharmacal Research, vol. 33, no. 11, pp. 1753-1760, 2010.

[38] K. Yamamoto and T. Kimura, "Orally and topically administered Sparassis crispa (Hanabiratake) improves healing of skin wounds in mice with streptozotocin-induced diabetes ," Bioscience, Biotechnology, and Biochemistry. In press.

[39] K. Yamamoto and T. Kimura, "Dietary Sparassis crispa (Hanabiratake) ameliorates plasma levels of adiponectin and glucose in type 2 diabetic mice," Journal of Health Science, vol. 56, no. 5, pp. 541-546, 2010.

[40] S. Wu, T. F. Lu, S. Wu, and W. J. Guan, "Research progress in G protein-coupled receptor 40," Yi Chuan, vol. 35, no. 4, pp. 27-34, 2013.

[41] K. Yoshikawa, T. Hashimoto, A. Hirasawa et al., "Unsaturated fatty acids derived from Sparassis crispa fruiting body and/or mycelium for inhibiting diabetes mellitus," Japanese Kokai Tokkyo Koho, P2010-59106A (March, 2010).

[42] A. H. Kwon, Z. Qiu, M. Hashimoto, K. Yamamoto, and T. Kimura, "Effects of medicinal mushroom (Sparassis crispa) on wound healing in streptozotocin-induced diabetic rats," American Journal of Surgery, vol. 197, no. 4, pp. 503-509, 2009.

[43] K. Yamamoto, Y. Nishikawa, T. Kimura, M. Dombo, N. Matsuura, and A. Sugitachi, "Antitumor activities of low molecular weight fraction derived from the cultured fruit body of Sparassis crispa in tumor-bearing mice," Nippon Shokuhin Kagaku Kogaku Kaishi, vol. 54, no. 9, pp. 419-423, 2007.

[44] M. Yao, K. Yamamoto, T. Kimura, and M. Dombo, "Effects of Hanabiratake (Sparassis crispa) on allergic rhinitis in OVAsensitized mice," Food Science and Technology Research, vol. 14, no. 6, pp. 589-594, 2008.

[45] H. H. Kim, S. Lee, T. S. Singh, J. K. Choi, T. Y. Shin, and S. H. Kim, "Sparassis crispa suppresses mast cell-mediated allergic inflammation: role of calcium, mitogen-activated protein kinase and nuclear factor- $\kappa \mathrm{B}$," International Journal of Molecular Medicine, vol. 30, no. 2, pp. 344-350, 2012.

[46] T. Kimura, "The physiological function of beta-glucan in Sparassis crispa," Food Processing and Ingredients, vol. 44, no. 11, pp. 14-15, 2009.

[47] N. Ohno, S. Nameda, T. Harada et al., "Immunomodulating activity of a beta-glucan preparation, SCG, extracted from a culinary-medicinal mushroom, Sparassis crispa Wulf.:Fr. (Aphyllophoromycetideae) and application to cancer patients," International Journal of Medicinal Mushrooms, vol. 5, pp. 359368, 2003.

[48] J. Chen, W. Gu, and K. Zhao, "The role of PI3K/Akt pathway in $\beta$-glucan-induced dendritic cell maturation," International Immunopharmacology, vol. 11, no. 4, p. 529, 2011.

[49] H. G. Park, Y. Y. Shim, S. O. Choi, and W. M. Park, "New method development for nanoparticle extraction of water-soluble $\beta$ $(1 \rightarrow 3)$-D-glucan from edible mushrooms, Sparassis crispa and Phellinus linteus," Journal of Agricultural and Food Chemistry, vol. 57, no. 6, pp. 2147-2154, 2009.

[50] T. Uchiyama, "Sparassis crispa extractions, resveratrol, and collagen peptide as antiaging agents and food supplements," Japanese Tokkyo Koho, P5016535 (June, 2012). 

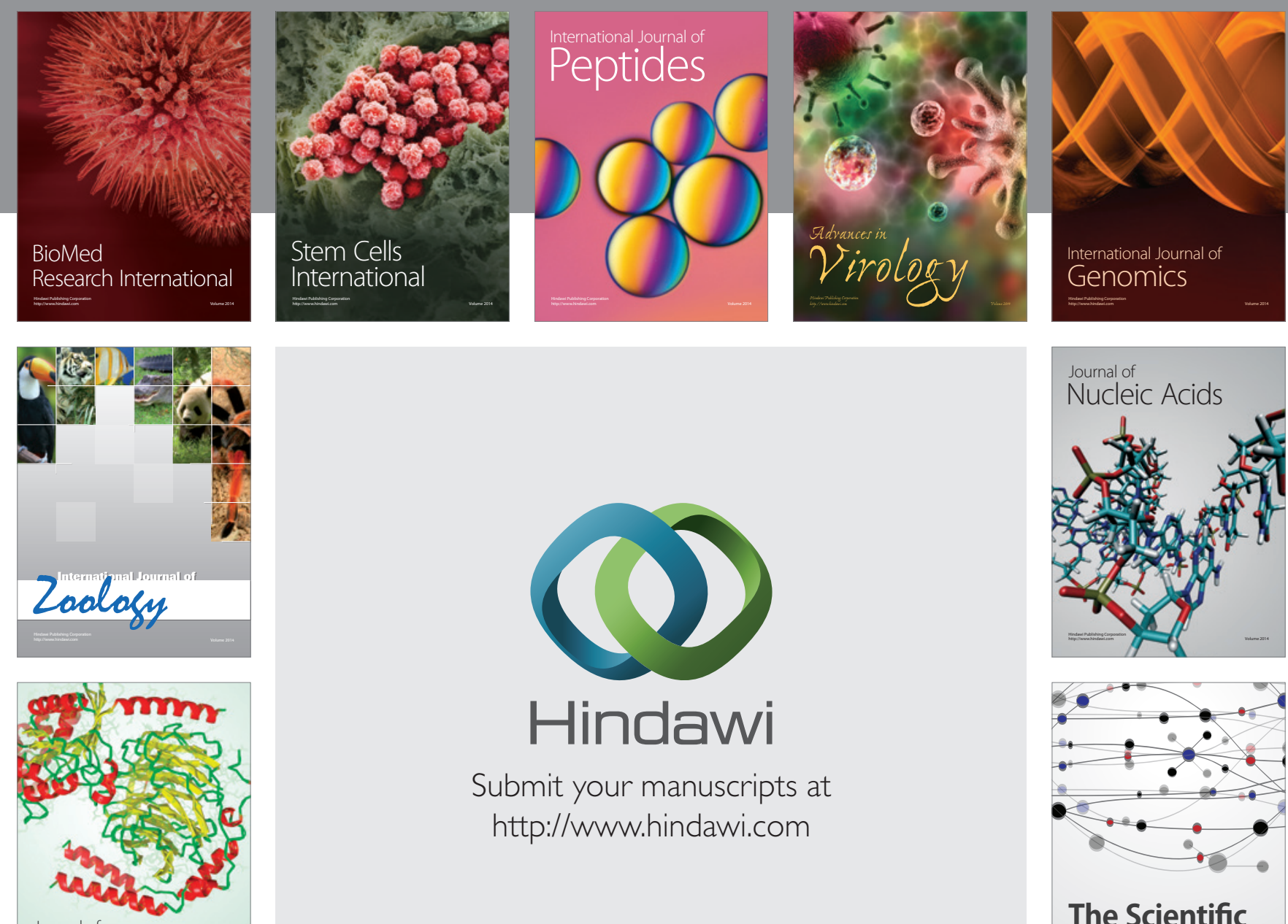

Submit your manuscripts at

http://www.hindawi.com

Journal of
Signal Transduction
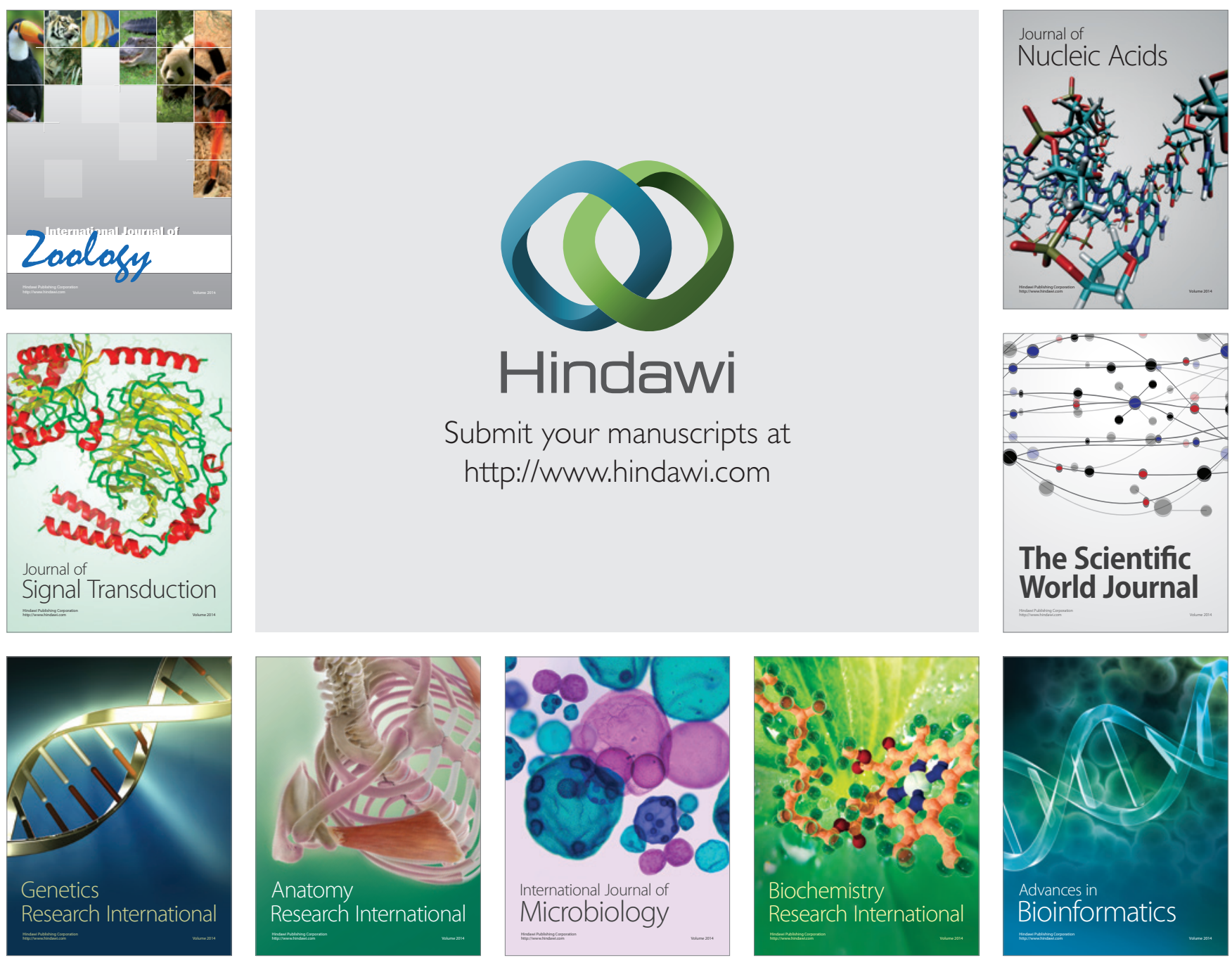

The Scientific World Journal
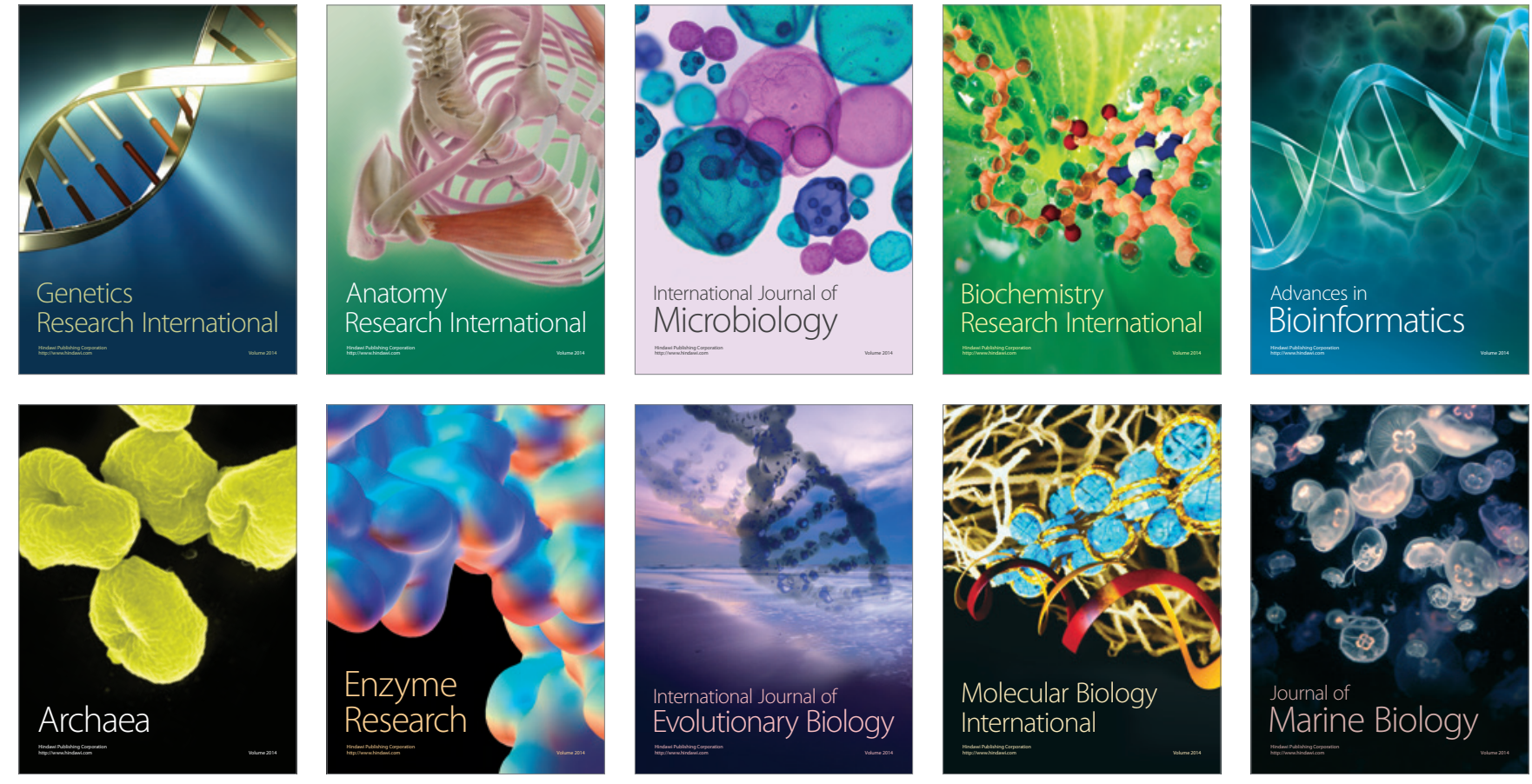